\title{
Teaching NeuroImages: Spinal cord herniation after cervical corpectomy
}

Melike Guryildirim, MD, Mehmet Kocak, MD, and Sumeet G. Dua, MD

Neurology ${ }^{\circledR}$ 2019;93:e1744. doi:10.1212/WNL.0000000000008401
Correspondence

Dr. Guryildirim

mguryil1@jhmi.edu

Figure Imaging
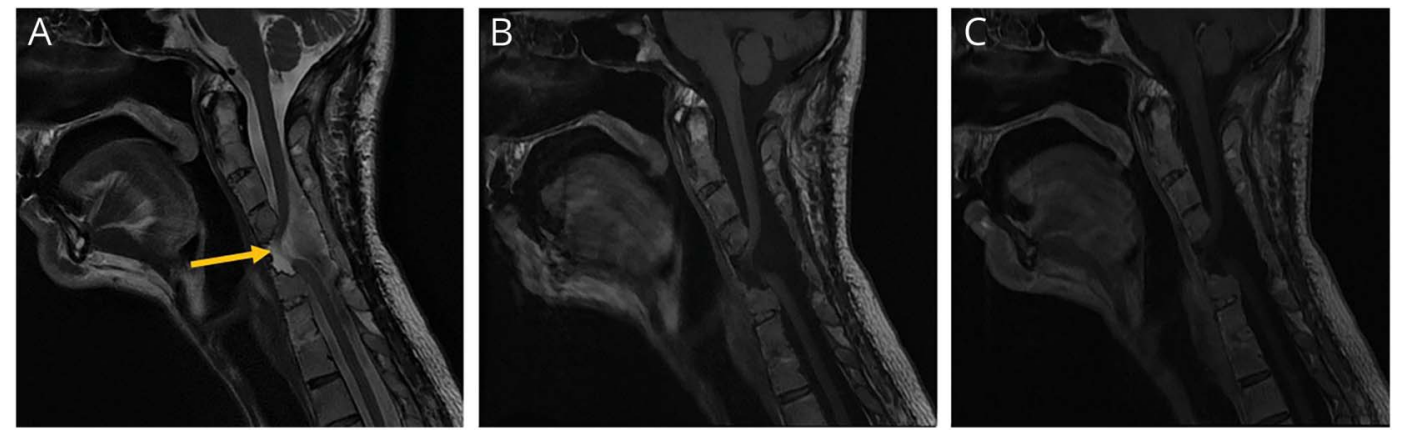

MRI shows spinal cord herniation into the C5 corpectomy defect ([A] sagittal T2-weighted image, [B] sagittal T1-weighted image without contrast, [C] sagittal T1-weighted image with contrast). Sagittal T2-weighted MRI shows herniation of the spinal cord anteriorly into the C5 corpectomy defect. There is marked thinning of the cervical cord at this level with abnormal T2 hyperintensity, compatible with myelomalacia (arrow in A). Precontrast and postcontrast T1weighted images do not demonstrate any abnormal enhancement.

A 48-year-old man presented with worsening generalized pain. He had a history of complex cervical deformity and C2-T4 anterior and posterior instrumented fusions. On neurologic examination, cranial nerves, sensation, and strength were intact. Imaging demonstrated herniation of the spinal cord into the corpectomy defect and myelomalacia of the herniated cord (figure). Components of the patient's pain were attributed to myelomalacia. Spinal cord herniation $(\mathrm{SCH})$, when iatrogenic, mostly occurs in the setting of posterior instrumentation and associated pseudomeningocele formation. $\mathrm{SCH}$ may also develop as a complication of anterior cervical decompression and underlying dural defect is the most likely mechanism. ${ }^{1,2}$

\section{Author contributions}

M. Guryildirim: drafting/revising the manuscript, data acquisition, study concept or design, analysis or interpretation of data, accepts responsibility for conduct of research and final approval, study supervision. M. Kocak: drafting/revising the manuscript, analysis or interpretation of data, accepts responsibility for conduct of research and final approval, study supervision. S.G. Dua: drafting/revising the manuscript, accepts responsibility for conduct of research and final approval, intellectual input.

\section{Study funding}

No targeted funding reported.

\section{Disclosure}

The authors report no disclosures relevant to the manuscript. Go to Neurology.org/N for full disclosures.

\section{References}

1. Guppy KH, Silverthorn JW. Spinal cord herniation after cervical corpectomy with cerebrospinal fluid leak: case report and review of the literature. World Neurosurg 2017;100:711.e7-711.e12.

2. Min JH, Jung BJ, Jang JS, Kim SK, Jung DJ, Lee SH. Spinal cord herniation after multilevel anterior cervical corpectomy and fusion for ossification of the posterior longitudinal ligament of the cervical spine. J Neurosurg Spine 2009;10:240-243.

\section{MORE ONLINE}

$\rightarrow$ Teaching slides

links.lww.com/WNL/

A986

From the Department of Diagnostic Radiology and Nuclear Medicine, Rush University Medical Center, Chicago, IL.

Go to Neurology.org/N for full disclosures. 


\section{Neurology}

\section{Teaching NeuroImages: Spinal cord herniation after cervical corpectomy Melike Guryildirim, Mehmet Kocak and Sumeet G. Dua Neurology 2019;93; 1744 \\ DOI 10.1212/WNL.0000000000008401}

This information is current as of October 28, 2019

\section{Updated Information \& Services}

References

Subspecialty Collections

Permissions \& Licensing

Reprints including high resolution figures, can be found at: http://n.neurology.org/content/93/18/e1744.full

This article cites 2 articles, 0 of which you can access for free at: http://n.neurology.org/content/93/18/e1744.full\#ref-list-1

This article, along with others on similar topics, appears in the following collection(s):

All Pain

http://n.neurology.org/cgi/collection/all_pain

All Spinal Cord

http://n.neurology.org/cgi/collection/all_spinal_cord

Information about reproducing this article in parts (figures,tables) or in its entirety can be found online at:

http://www.neurology.org/about/about_the_journal\#permissions

Information about ordering reprints can be found online:

http://n.neurology.org/subscribers/advertise

Neurology ${ }^{\circledR}$ is the official journal of the American Academy of Neurology. Published continuously since 1951, it is now a weekly with 48 issues per year. Copyright @ 2019 American Academy of Neurology. All rights reserved. Print ISSN: 0028-3878. Online ISSN: 1526-632X.

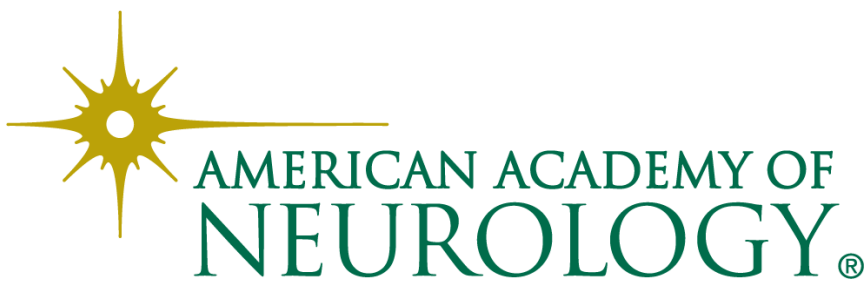

